\title{
キクの電照栽培における電照期間と花芽分化抑制に必要な放射照度との関係
}

\author{
白山竜次 ${ }^{1 *} \cdot$ 永吉実孝 $^{2} \cdot$ 郡山啓作 $^{1}$ \\ 1 鹿児島県農業開発総合センター花き部８91-0513＼cjkstart鹿児島県指宿市山川岡児ヶ水 \\ 2 鹿児島県バイオテクノロジー研究所８93-1601＼cjkstart鹿児島県鹿屋市串良町細山田
}

\section{Relation between Night-break-lighting Period and Light Irradiance Intensity to Inhibit Flower Initiation in Chrysanthemum}

\author{
Ryuji Hakuzan $^{1 *}$, Sanetaka Nagayoshi ${ }^{2}$ and Keisaku Kooriyama ${ }^{1}$ \\ ${ }^{1}$ Kagoshima Prefectural Institute for Agricultural Development Flower Section. Ibusuki, Kagoshima 891-0513 \\ ${ }^{2}$ Kagoshima Biotechnology Institute. Kanoya, Kagoshima 893-1601
}

\begin{abstract}
The relation between the night-break-lighting period and light irradiance intensity to inhibit flower initiation in chrysanthemum was investigated using 'Iwanohakusen' and 'Jinba', major summer-to-autumn and autumn flowering cultivars in Japan, respectively. Plants were subjected to night-break with different light irradiance intensities for 20 to 60 or 70 days from planting. The required light irradiance intensity to inhibit flower initiation was evaluated by the number of nodes on the main stem at flowering. The required light irradiance intensity increased as the night-break-lighting period became longer in both cultivars. In 'Iwanohakusen', flowering could not be prevented by night-break when the lighting period reached 60 days. On the other hand, flower initiation in 'Jinba' was inhibited successfully by night-break even though the lighting period reached 70 days. These results indicate that the light irradiance intensity of night-break should be higher when the lighting period is longer than a threshold, depending on cultivars.
\end{abstract}

Key Words : flowering, fluorescent lamp, summer-to-autumn flowering chrysanthemum キーワード：開花，夏秋ギク，蛍光灯

\begin{abstract}
緒 言
キクは短日植物で，電照による長日処理を行らことによ り，人為的に花芽分化を抑制して開花時期の調整や草丈の 確保を行っている. 産地では, 夏季は限界日長の長い夏秋 ギク型品種（以下，夏秋ギク）, 秋から春にかけては限界日 長の短い秋ギク型品種（以下，秋ギク）を用いて, 暗期中 断による周年生産体系が確立されており, 電照による日長 制御はキク栽培の基盤技術のひとつとなっている（大石, 2011).

キク栽培では, 切り花長を確保するために電照期間を長 くすると, 電照による花芽分化抑制効果が低下し, 柳葉の 増加や早期発蕾が発生することが知られている. Cockshull （1976）は，キクは電照による暗期中断条件下でも花芽分化 を開始し，長日下に抢ける花芽分化節位を長日下花芽分化 節位（LDLN）と称して, LDLN には品種間差があるとし
\end{abstract}

2012 年 8 月 25 日 受付. 2013 年 1 月 20 日 受理.

本研究の一部は, 農林水産省「新たな農林水産政策を推進する 実用技術開発事業」に执いて行われた。

* Corresponding auther. E-mail: hakuzan@pref.kagoshima.lg.jp
た．福田（1995）は秋ギク ‘秀芳の力’を用いて，電照期 間を 45 ～ 60 日とした場合，栄養成長期間が長くなるほど 柳葉数が増加するため, 電照期間は概ね 50 日以内とし, 消 灯前は電照時間を長くすることが望ましいとした。 また夏 秋ギク ‘精雲’ においても栄養成長期間 7 週以上になると 電照抑制が効かなくなるとした，出口ら（2002）は夏秋ギ ク ‘岩の白扇’を用いて，電照期間を $40 ， 45$ および 50 日 の 3 段階に設定し，電照期間が長くなる汪ど柳葉の発生が 増加することから, 展開葉数 25 枚以内で消灯することによ り柳葉を防止できるとした，以上のように，LDLNの品種 間差や電照期間が長くなると電照による花芽分化抑制効果 が低下することは報告されているが，電照期間と花芽分化 抑制に必要な暗期中断の放射照度との関係について詳細に 検討した報告は見当たらない，近年，省エネルギー対策に よる代替光源への移行推進の動きから，キクの電照用光源 が白熱電球から蛍光灯や発光ダイオード (LED) へ移行し つつある。そこで本試験では，近年導入が進んでいる蛍光 灯を光源として，電照期間を変えることで花芽分化抑制に 必要な暗期中断の放射照度がぞのように変化するかを，代 表的な夏秋ギク ‘岩の白扇’および秋ギク ‘神馬’を用い て，定量しょうと試みた。 


\section{材料および方法}

\section{1. 共通の試験方法}

キクの電照期間と花芽分化抑制に必要な光量の変化を検 証するためには，放射照度を変える方法と電照時間を変え る方法がある. しかし，暗期中断は点灯する時間帯によっ て花芽抑制の効果が変化する可能性がある（Cathey・Borthwick, 1964）ため, 本試験では放射照度を変える方法を用い た. 試験は鹿児島県農業開発総合センター花き部内の硬質 プラスチックハウスで行った. 光源は三波長型赤色蛍光灯 （YOF-23EP, 消費電力 $23 \mathrm{~W}$, 寄の会）を用いた. この蛍光 灯は花芽分化抑制に有効とされている赤色光を多く含む蛍 光灯（第 1 図）で，R/FR 比は 8.9 であり, キクの産地でも 近年導入されているものである. 光源は, ‘岩の白扇’では

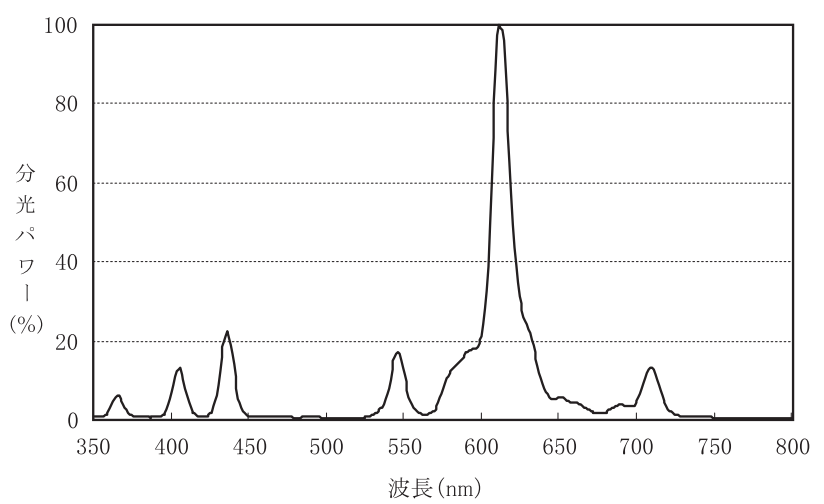

第 1 図 赤色蛍光灯の波長特性

分光パワーはピーク波長の放射照度を100とした場合の 各波長ごとの割合を示す

測定機材 : 英光精機製 分光放射照度計 MS-720（八口 ゲン補正済み)

2010 年 8 月 点灯 1 時間後に測定

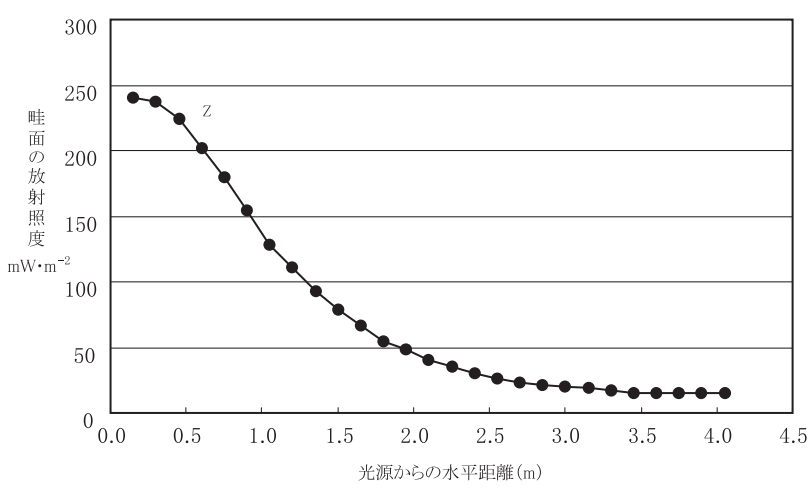

第 2 図光源からの水平距離と畦面の放射照度の関係 zデータは ‘岩の白扇’ 電照期間 30 日区における実測值 使用機材：Delta OHM 社製放射照度計 HD2102.2, 放射 照度プローブ LP471RAD

光源 : $23 \mathrm{~W}$ 三波長型赤色蛍光灯 (型式 YOF-23EP), 設 置高さ：畘面加 $1.5 \mathrm{~m}$

2010 年 5 月 点灯 1 時間後に光源直下から $0.15 \mathrm{~m}$ 間隔 で測定
畔面より $1.5 \mathrm{~m}$ の高さに，“神馬’では $1.7 \mathrm{~m}$ の高さに設置 した. 光源から $30 \mathrm{~cm}$ 横に遮光シート（ホワイトシルバー, トーカン）を遮光用に設置して, “岩の白扇’ は $4 \mathrm{~m}$ 間隔, “神馬”は $3 \mathrm{~m}$ 間隔で, 各電照期間の試験区を設けた。 そ れぞれの区では，光源から離れることによる放射照度の低 下（第 2 図）を利用して，異なる放射照度の影響を調査し た. 放射照度の測定には $400 \sim 1,050 \mathrm{~nm}$ の波長域に感度を 持つプローブ（LP471RAD， Delta OHM）を装着した放射 照度計（HD2102.2，Delta OHM）を用いた。試験区内では 光源直下から $15 \mathrm{~cm}$ ごとに放射照度を測定し, “岩の白扇” は27 分割, “神馬’ は2 0 分割とした. 栽植様式は床幅 $90 \mathrm{~cm}$ の平畘に $15 \mathrm{~cm} \cdot 6$ 目ネットを用いて，1 目当たり 2 本植え とし中央 2 列を空けて (2-2-0-0-2-2)，同一放射照度の位置 に 8 株を植付けた. 栽培は無摘心で行った. 電照期間とし て，夏秋ギク ‘岩の白扇’ では無電照区，20，30，40，50 および 60 日間の 6 区を, 秋ギク ‘神馬’では無電照区，20， 30，40，50，60 抢よび 70 日間の 7 区を設置した．調査は消 灯時の葉数および開花時の葉数を試験区ごとに計測した.

放射照度と展開葉数の関係は回帰を用いた統計的手法で 解析可能であるが，直線回帰や曲線回帰があてはめにくい 場合は，複数の直線を連続的にあてはめた折れ線回帰モデ ルが適用できる（大塚，1995）。本試験では，放射照度が強 くなるほど展開葉数が増加し，特定の放射照度以上では展 開葉数が一定となる傾向を統計的に明らかにするため, 2 本の直線による折れ線回帰分析（濱野ら，1987; 村元ら, 1997; 大塚・吉原，1975; Vieth, 1989）を適用し，2 本の回帰 直線の交点となる放射照度を求めた。

統計処理は，フリーソフトウエア R（ver. 2.15.1）に青木 （2009）の作成した折れ線回帰の関数式（http://aoki2.si. gunma-u.ac.jp/R/oresen.html）を用いて行った.

\section{2. 夏秋ギク ‘岩の白扇’ における電照期間と花芽分化抑 制に必要な放射照度（試験 1)}

2010 年 5 月 24 日に前歴の揃った発根苗を定植した. 施 肥は $\mathrm{N}: \mathrm{P}_{2} \mathrm{O}_{5}: \mathrm{K}_{2} \mathrm{O}=2.4: 1.6: 1.6 \mathrm{~kg} ・ \mathrm{a}^{-1}$ で, 電照は 5 時間 （22:00〜翌 3:00）の暗期中断とした. 定植直後から無電照 区を除いて電照を開始し，各区の電照期間に応じて順次消 灯した. 温度管理は $25^{\circ} \mathrm{C} て ゙$ 換気を行い, 暖房機による加 温はしなかった.

\section{3. 秋ギク ‘神馬’ における電照期間と花芽分化抑制に必 要な放射照度（試験 2)}

2011 年 9 月 12 日に前歴の揃った発根苗を定植した. 施 肥は $\mathrm{N}: \mathrm{P}_{2} \mathrm{O}_{5}: \mathrm{K}_{2} \mathrm{O}=1.6: 0.8: 0.8 \mathrm{~kg} \cdot \mathrm{a}^{-1}$ で, 電照時間は, 暗期中断 2 時間（24:00〜翌 2:00） とした. 定植直後から 無電照区を除いて電照を開始し，各区の電照期間に応じて 順次消灯した．温度管理は $25^{\circ} \mathrm{C} て ゙$ 換気を行い，気温が低 下してからは最低夜温 $17^{\circ} \mathrm{C} て ゙$ 加温した。 


\section{結 果}

\section{1. 夏秋ギク ‘岩の白扇’ における電照期間と花芽分化抑} 制に必要な放射照度（試験 1)

第 3 図に各電照期間に打福放射照度と開花時展開葉数 の分布を示した. 2 本の直線による折れ線回帰によって花 芽分化抑制の閾值と推定された放射照度 (以後, 閾値と記 す）は，電照期間 20，30，40 お。び 50 日区で各々 45，57， 75 打よび $124 \mathrm{~mW} \cdot \mathrm{m}^{-2}$ で，閾值より強い放射照度では開 花時展開葉数が変化しないのに対し，それより弱い放射照 度では開花時展開葉数が放射照度に比例して増加した。電 照期間 60 日区では 50 日区までと異なり, 閾値より強い放 射照度でも開花時展開葉数が増加する傾向が夕られ，他区 と同様な閾值が推定できなかった。第 1 表に光源直下付近 の放射照度 $180 \sim 261 \mathrm{~mW} \cdot \mathrm{m}^{-2}$ の範囲内の 40 株に打汀る 各電照期間の消灯時葉数, 消灯後増加葉数および開花時展 開葉数について示した。 また第 3 図に示した花芽分化抑制
第 1 表 夏秋ギク “岩の白扇’ に打正照期間と光源直下の 展開葉数との関係抒よび葉数が減少する放射照度の閾値

\begin{tabular}{ccccc}
\hline \hline 電照期間 & 消灯時葉数 & $\begin{array}{c}\text { 消灯後 } \\
\text { 増加葉数 }\end{array}$ & $\begin{array}{c}\text { 開花時 } \\
\text { 展開葉数 }\end{array}$ & $\begin{array}{c}\text { 閾値の } \\
\text { 放射照度 }\end{array}$ \\
\hline 無電照 & - & - & $29.8 \mathrm{a}^{\mathrm{x}}$ & - \\
20 日 & $14.7 \mathrm{a}^{\mathrm{x}}$ & $22.2 \mathrm{a}^{\mathrm{x}}$ & $36.8 \mathrm{~b}$ & 45.0 \\
30 日 & $19.1 \mathrm{~b}$ & $20.2 \mathrm{a}$ & $39.3 \mathrm{c}$ & 56.8 \\
40 日 & $23.7 \mathrm{c}$ & $21.7 \mathrm{a}$ & $45.4 \mathrm{~d}$ & 74.5 \\
50 日 & $29.3 \mathrm{~d}$ & $21.0 \mathrm{a}$ & $50.2 \mathrm{e}$ & 124.3 \\
60 日 & $35.6 \mathrm{e}$ & $17.4 \mathrm{~b}$ & $53.0 \mathrm{f}$ & $261<\mathrm{w}$
\end{tabular}

${ }^{\mathrm{z}}$ 光源直下付近の放射照度 $180 \sim 261 \mathrm{~mW} \cdot \mathrm{m}^{-2}$ の範囲内の 40 株を対象とした

$\mathrm{y}$ 放射照度は 2 直線の折線回帰による交点の值を花芽分化抑 制の閾値とした

x 異なるアルファベット文字間は Tukey-kramerの多重検定に より $1 \%$ 水準で有意差あり

w ‘261<’は，有効な閾值が得られず，閾值がこの放射照度 以上である可能性を示す

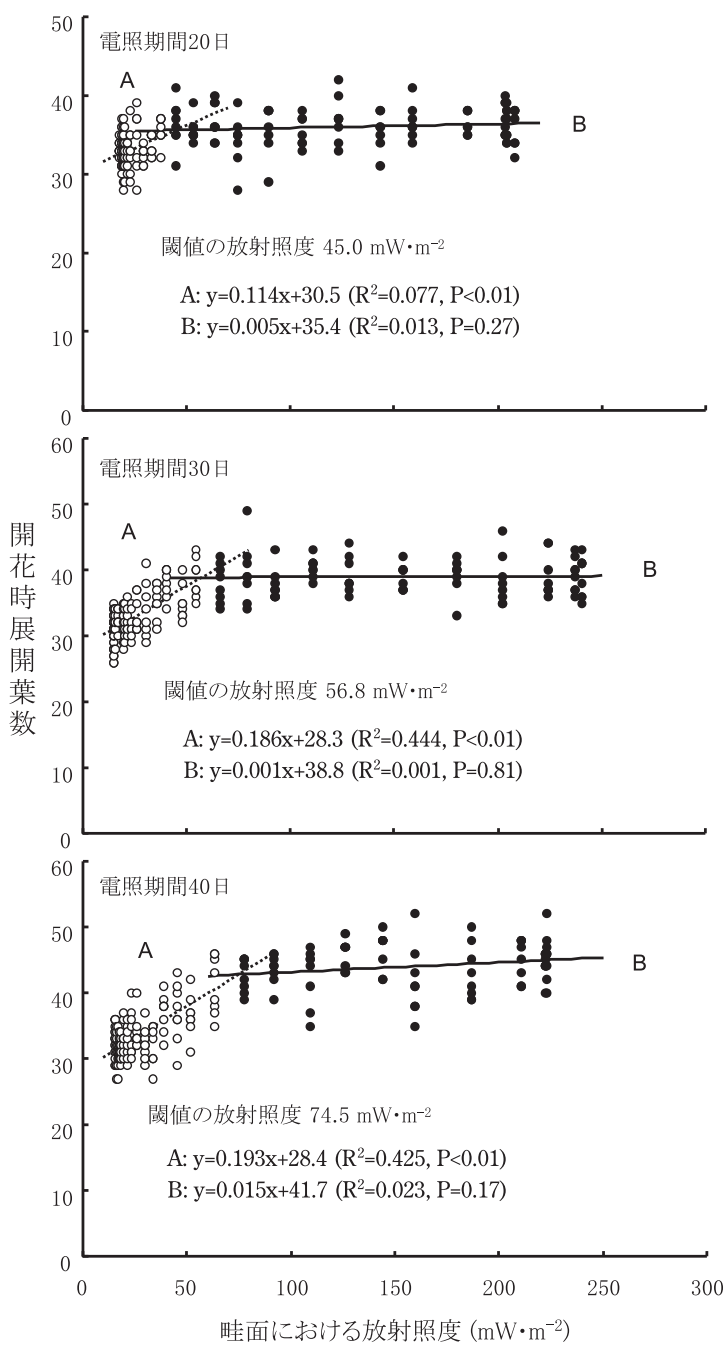

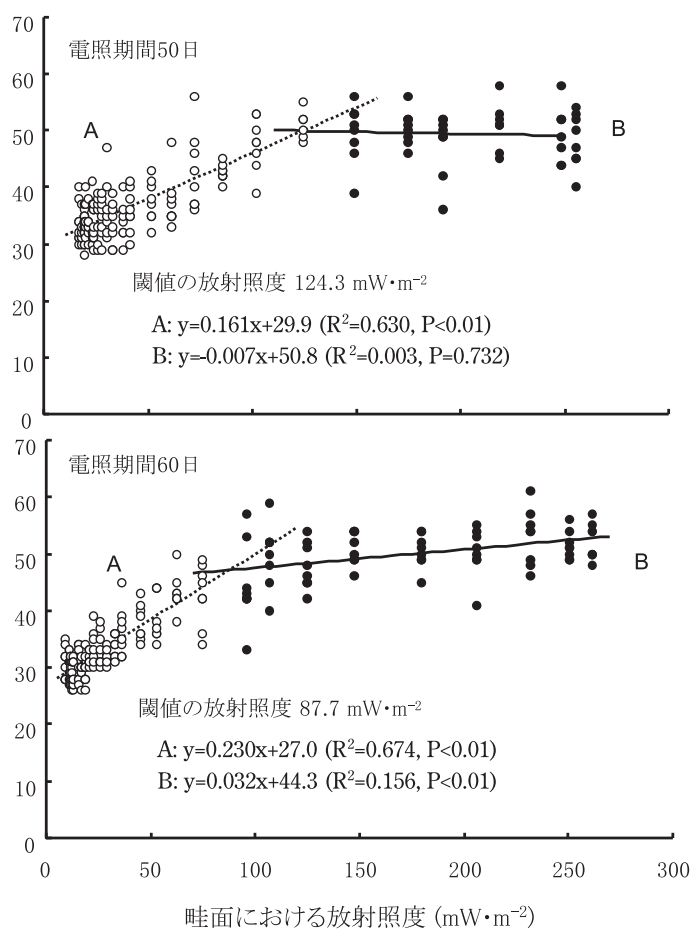

第 3 図 電照期間と暗期中断電照の放射照度が夏秋ギク ‘岩の白扇’の開花までの展開葉数に及ぼす影響 図中の○拈よびのは二本の直線による折れ線回帰分析により得られた直線 A, B の成分を示す 

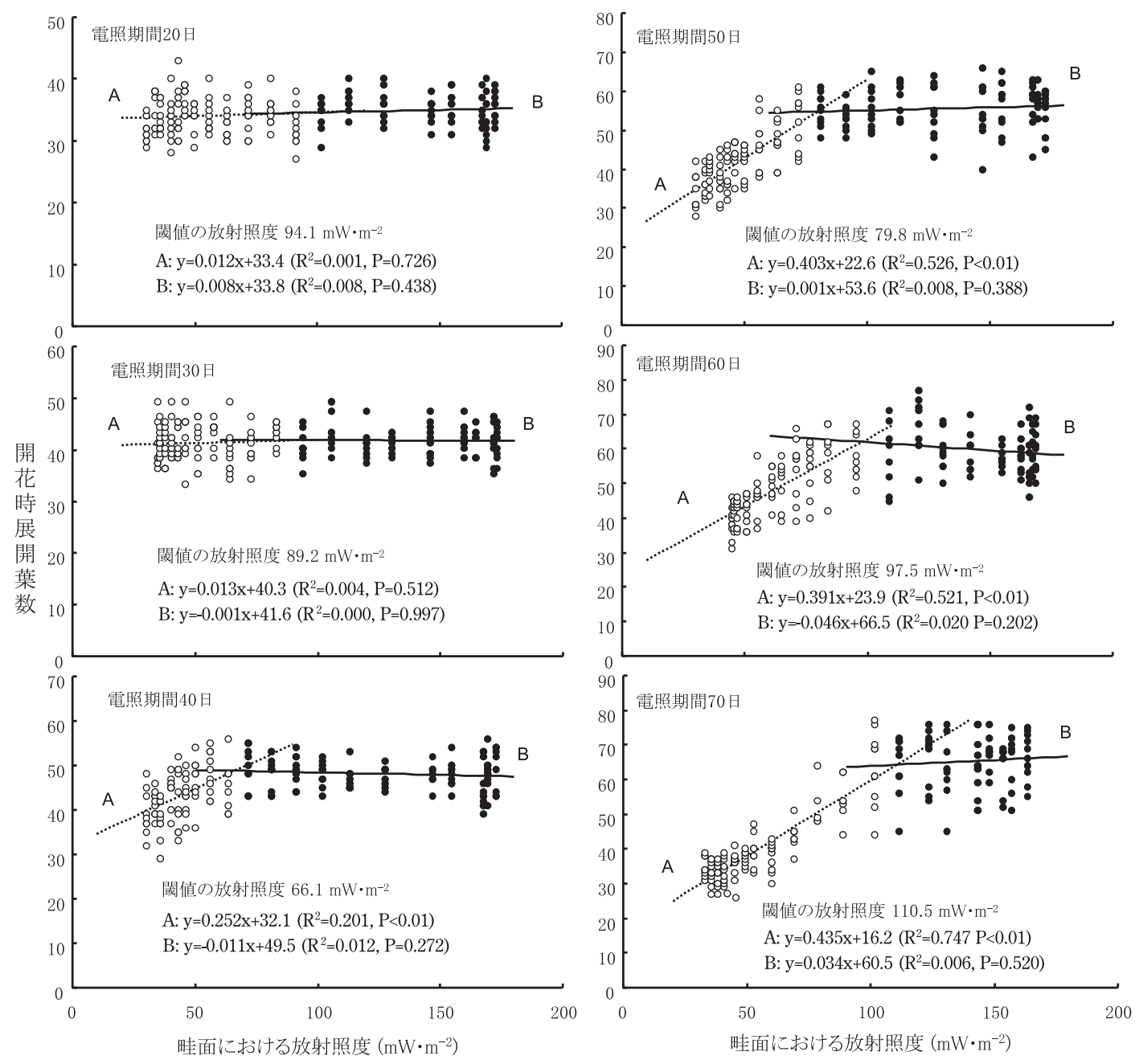

第 4 図 電照期間と暗期中断電照の放射照度が秋ギク ‘神馬’の開花までの展開葉数に及ぼす影響 図中の○抽○は二本の直線による折れ線回帰分析により得られた直線 $\mathrm{A}, \mathrm{B}$ の成分を示す

放射照度の推定閾値を各区ごとに示した，消灯時葉数抢よ び開花時展開葉数は, 電照期間が長くなるにつれて有意に 増加した. 消灯後増加葉数は電照期間 $20 \sim 50$ 日区には差 がなく，60日区では有意に少なかった．

\section{2. 秋ギク “神馬’ における電照期間と花芽分化抑制に必 要な放射照度（試験 2）}

第 4 図に各電照期間に打ける放射照度と開花時展開葉数 の分布を示した．花芽分化抑制効果が低下寸る放射照度の 閾值の推定については, ‘岩の白扇’ と同様に 2 本の直線に よる折孔線回帰分析を用いた。電照期間 40，50，60 および 70 日区の閾值は，各々 $66 ， 80,98$ および $111 \mathrm{~mW} \cdot \mathrm{m}^{-2}$ と 推定された. しかし, 電照期間 20 日区と 30 日区では, 放 射照度によって開花時展開葉数が増加するような直線が有 意に推定できず，他区と同様の閾值が得られなかった．第 2 表に光源直下付近の放射照度 $110 \sim 192 \mathrm{~mW} \cdot \mathrm{m}^{-2}$ の範囲 内の 40 株に抢ける消灯時葉数, 消灯後増加葉数および開花 時展開葉数について示した。 また第 4 図に示した花芽分化 抑制放射照度の推定閾値を各区ごとに示した．消灯時葉数
第 2 表 秋ギク ‘神馬’に打ける電照期間と光源直下の展開葉 数との関係扣よび葉数が減少する放射照度の閾值 ${ }^{2}$

\begin{tabular}{ccccc}
\hline \hline 電照期間 & 消灯時葉数 & $\begin{array}{c}\text { 消灯後 } \\
\text { 増加葉数 }\end{array}$ & $\begin{array}{c}\text { 開花時 } \\
\text { 展開葉数 }\end{array}$ & $\begin{array}{c}\text { 閾值の } \\
\text { 放射照度 }\end{array}$ \\
\hline 無電照 & - & - & $25.5 \mathrm{a}^{\mathrm{x}}$ & - \\
20 日 & $15.2 \mathrm{a}^{\mathrm{x}}$ & $19.2 \mathrm{a}^{\mathrm{x}}$ & $34.4 \mathrm{~b}$ & $<30.2^{\mathrm{w}}$ \\
30 日 & $22.4 \mathrm{~b}$ & $18.9 \mathrm{a}$ & $41.3 \mathrm{c}$ & $<34.7^{\mathrm{w}}$ \\
40 日 & $28.5 \mathrm{c}$ & $19.0 \mathrm{a}$ & $47.5 \mathrm{~d}$ & 66.1 \\
50 日 & $36.9 \mathrm{~d}$ & $18.7 \mathrm{a}$ & $55.6 \mathrm{e}$ & 79.8 \\
60 日 & $40.8 \mathrm{e}$ & $19.0 \mathrm{a}$ & $59.8 \mathrm{f}$ & 97.5 \\
70 日 & $47.4 \mathrm{f}$ & $18.7 \mathrm{a}$ & $66.1 \mathrm{~g}$ & 110.5 \\
\hline
\end{tabular}

$\mathrm{z}$ 光源直下付近の放射照度 $110 \sim 192 \mathrm{~mW} \cdot \mathrm{m}^{-2}$ の範囲内の 40 株を対象とした

$\mathrm{y}$ 放射照度は 2 直線の折線回帰による交点の值を花芽分化抑 制の閾値とした

x 異なるアルファベット文字間はTukey-kramer の多重検定に より $1 \%$ 水準で有意差あり

"w 20 日区の ‘ $30.2 ’$ および 30 日区の ‘ $<34.7$ は，有効な閾 值が得られず，閾值がこの放射照度以下である可能性を示 す 
および開花時展開葉数は, 電照期間が長くなるにつれて有 意に増加した. 消灯後増加葉数は概ね $18 \sim 20$ 枚前後で電 照期間 $20 〜 70$ 日では有意な差は認められなかった。

\section{考察}

キクの電照栽培に関する報告は多数見受けられるが, 電 照期間と花芽分化抑制に必要な光量の関係について詳細に 検討した報告は少なく, 電照期間が長くなるにつれて, 花 芽分化抑制に必要な暗期中断の放射照度がぞのように変化 するかは明らかではなかった，本試験の結果から，キクの 電照期間が長くなるにつれて，花芽分化抑制に必要な暗期 中断の放射照度の閾值が高くなること, また閾值の変化は 品種によって異なることが示された.

夏秋ギク ‘岩の白扇’ の場合, 電照期間 20 日区でも放射 照度 $45 \mathrm{~mW} \cdot \mathrm{m}^{-2}$ 以下では，花芽分化の抑制が不十分であ り, 電照期間が長くなるにつれて花芽分化抑制に必要な放 射照度の閾値も高くなった. 電照抑制効果が十分であれば, 消灯後増加葉数は “岩の白扇” の場合 20 枚前後であり, 電 照期間 60 日区は，電照直下の放射照度 $261 \mathrm{~mW} \cdot \mathrm{m}^{-2}$ でも 十分な花芽分化抑制効果は得られず，電照期間中に花芽分 化したものと考えられた. 従って電照期間 60 日区の花芽分 化抑制に必要な放射照度は光源直下の $261 \mathrm{~mW} \cdot \mathrm{m}^{-2}$ 以上 か, または本試験環境下では 60 日以前に LDLN に達して いたと推察された. 一方, 秋ギク ‘神馬’の場合, 電照期 間 20 日区，30日区では，試験区の最低放射照度でも十分 な花芽分化抑制効果が得られ，また第 2 表に示すように無 電照区に対して開花時展開葉数の有意な差が認められるこ とから, 閾値となる放射照度は電照期間 20 日区では $30 \mathrm{~mW}$ $\mathrm{m}^{-2}$, 30 日区では $35 \mathrm{~mW} \cdot \mathrm{m}^{-2}$ より低いと推察された。電 照期間40日区以降は電照期間が長くなるにつれて花芽分化 抑制に必要な放射照度の閾值が段階的に高くなる傾向に あったが，電照期間 70 日区でも放射照度 $111 \mathrm{~mW} \cdot \mathrm{m}^{-2}$ 以 上では十分な花芽分化抑制効果が得られることが示され た.このように，両品種ともに電照期間が長くなるにつれ て，花芽分化抑制に必要な放射照度の閾值が段階的に高く なったが，“岩の白扇’は電照期間が長くなるにつれて急激 に花芽分化抑制に必要な放射照度閾值が高くなるのに対し

第 3 表 各品種に打ける消灯前後の施設内気温の概要 ${ }^{\mathrm{z}}$

\begin{tabular}{|c|c|c|c|c|}
\hline \multirow{2}{*}{ 電照期間 } & \multicolumn{2}{|c|}{ ‘岩の白扇’ } & \multicolumn{2}{|c|}{ ‘神馬’ } \\
\hline & 昼温 $\left({ }^{\circ} \mathrm{C}\right)$ & 夜温 $\left({ }^{\circ} \mathrm{C}\right)^{y}$ & 昼温 $\left({ }^{\circ} \mathrm{C}\right)$ & 夜温 $\left({ }^{\circ} \mathrm{C}\right)^{\mathrm{x}}$ \\
\hline 20 日 & 26.7 & 22.1 & 26.3 & 21.4 \\
\hline 30 日 & 27.2 & 23.9 & 25.7 & 20.3 \\
\hline 40 日 & 28.4 & 24.6 & 23.8 & 17.3 \\
\hline 50 日 & 30.6 & 25.1 & 24.6 & 19.7 \\
\hline 60 日 & 32.8 & 25.9 & 22.4 & 17.7 \\
\hline 70 日 & & & 22.1 & 17.9 \\
\hline
\end{tabular}

$\mathrm{z}$ 消灯前後 10 日間の施設内気温

$\mathrm{y}$ 昼温は $6: 00 \sim 18: 00$, 夜温は 19:00〜5:00 における平均気温

$\mathrm{x}$ 昼温は 7:00〜18:00, 夜温は 19:00〜6:00 に打列平均気温
て，“神馬’は比較的緩やかであった．現場では電照期間中 の早期発蕾が ‘岩の白扇’で問題になっており，その原因 については,このよらな電照期間と閾値の変化の品種間差 異が一因である可能性が考えられる.

本試験で行った花芽分化抑制に必要な放射照度を光源か らの距離による放射照度の変化で推定する手法について は, 植物の成長とともに, 光源と成長点の距離が変化する こと, 1 点の光源からの照射のため, 光源に対する水平距 離の違いにより, 植物体の受光角度が変化することなど, いくつか考慮すべき点がある。キクの花芽分化抑制に必要 な暗期中断の光量は, 気温, 日射量などの外的要因で変化 することが知られている (Cockshull, 1979). 本試験は定植 日を揃えて段階的に消灯しているため，試験期間中の気象 変動が花芽分化抑制に必要な放射照度に影響を与えた可能 性についても考慮すべきである．第 3 表に両品種の各電照 期間に打ける消灯前後 10 日間の平均昼夜温を示した. キク の花芽分化には昼温よりも夜温の影響が大きいとされて抒 り, 品種にもよるが夜温は $25^{\circ} \mathrm{C}$ 以上, 昼温は $30^{\circ} \mathrm{C}$ 以上で 開花遅延を起こすとされている（西尾，1995）。“岩の白扇” では，電照期間の長い試験区ほど消灯前後の気温が高くな り，花芽分化適温から離れていく傾向にあった。 このこと は，電照期間の長い試験区での閾値の上昇を過小に評価し ている可能性が残る. 花芽分化に最適な温度条件下では, 花芽分化を抑制できる放射照度の閾値は，本実験よりもさ らに高い可能性がある。一方，“神馬’では，電照期間 20 〜 70 日区を通じて昼温, 夜温ともに花芽分化適温内にある ことから，花芽分化を抑制できる放射照度の閾値に対する 気温の影響は少ないと考えられる.

本試験は光源として赤色光を特異的に多く含む 3 波長型 蛍光灯を使用した。これまでキクの電照栽培に用いられる 光源は白熱電球が主体で，これまでの電照栽培に関する知 見も白熱電球によるものが多い(福田, 1995; 出口ら, 2002). 光源が異なると発せられる光の分光放射特性も異なるた め，遠赤色光を多く含む白熱灯や赤色光の割合の少ない昼 光色蛍光灯などとは花芽分化抑制の閾値と推定された放射 照度の值が異なることに留意すべきである.

以上のことからキク栽培では，電照期間の長さにより電 照抑制効果が変化することが示された。 そのため草丈を確 保するために電照期間を長くする場合は，放射照度を強く する，または 1 日の電照時間を長くするなどの対策をとる 必要がある. 一方, 慣行よりも電照期間を短くする場合, 放 射照度を低くすることも可能な場合があると考えられる.

\section{摘要}

夏秋ギク “岩の白扇’扎よび秋ギク“神馬’を用いて， 電照期間と花芽分化抑制に必要な放射照度との関係につい て試験を行った．電照期間は定植から 20〜60日までの 5 区（“神馬”は70日までの 6 区）を設置し，各区における 光源からの距離と光量減衰を利用して放射照度ごとに展開 
葉数の調査を行った. 展開葉数が増加から一定值へと変化 する放射照度の閾值の推定は, 2 本の直線による折孔線回 帰分析を用いた。 ‘岩の白扇’では, 電照期間が長くなるに つれて，花芽分化抑制飞必要な放射照度の閾値が高くなっ たが, 電照期間 50 日以降は閾値が急激に高くなり, 電照直 下付近の放射照度 $180 \sim 261 \mathrm{~mW} \cdot \mathrm{m}^{-2}$ でも, 電照中から花 芽分化が開始された。一方， “神馬” 女電照期間が長くなる につれて, 花芽分化抑制に必要な放射照度の閾值が高く なったが, その程度は緩やかで, 電照期間70日でも $110 \mathrm{~mW} ・$ $\mathrm{m}^{-2}$ 以上の放射照度で十分に花芽分化が抑制された. 以上 のことから，キクでは電照期間が長くなると花芽分化抑制 飞必要な放射照度の閾值が高くなることが明らかとなっ た．その程度には品種間差があり, “神馬”に比較して “岩 の白扇’で顕著であった，

\section{引用文献}

青木繁伸. 2009. 二本の直線による折孔線回帰. R による 統計処理. 〈http://aoki2.si.gunma-u.ac.jp/R/〉.

Cathey, H. M. and H. A. Borthwick. 1964. Significance of Dark Reversion of Phytochrome in Flowering of Chrysanthemum morifolium. Botan. Gaz. 125: 232-236.

Cockshull, K. E. 1976. Flower and leaf initiation by Chrysanthemum morifolium Ramat in long days. J. Hort. Sci. 51: 441450.

Cockshull, K. E. 1979. Effects of Irradiance and Temperature on
Flowering of Chrysanthemum morifolium Ramat in Continuous Light. Ann. Bot. 44: 451-460.

出口 浩・松尾崇宏・北村信弘. 2002. 無側枝性夏秋ギク 「岩の白扇」の6〜8月開花に打ける栽培安定技術. 長 崎総農林試研報. 28: 1-17.

福田正夫. 1995. 周年生産の技術大系. p. 341-350. 農業技 術体系 花卉 第6巻 キク。農文協. 東京.

濱野周泰・古賀 正・青木司光. 1987. 北沢清造園樹木に 括ける無給水日数と生存率ならびに土㙥水分の関連に ついて. 造園雑誌. 50: 155-160.

村元隆行 - 藤村 忍 - 門脇基二 ・ 石橋 晃. 1997. 比内地 鶏（ロードアイランドレッド $\times$ 比内鷄）のリジン要求 量. 日本畜産學會報. 68: 459-465.

西尾穣一. 1995. 発育相とそれを支配する要因, 調節技術. p. 139-149. 農業技術体系 花卉 第6巻 キク. 農文 協. 東京.

大石一史. 2011. キクの生育相. p. 76-85. 大石一史編著. キクをつくりこなす．農文協．東京.

大塚雍雄. 1995. 作物品種の生態的特性解析への折孔線回 帰モデルの適用. 育学雑. 45: 135-138.

大塚雍雄・吉原雅彦. 1975.1ないし2の折曲点をもつ折机 線モデルのあてはめ. 応用統計学. 5: 29-39.

Vieth E. 1989. Fitting piecewise linear regression functions to biological responses. J. Appl. Physiol. 67: 390-396. 